\title{
Much Cry and Little Wool: Judicial Mediation Policy in Action in W Court
}

\author{
Xin Xin \\ PhD candidate, School of Law, \\ City University of Hong Kong.
}

\section{Doi:10.5901/mjss.2013.v4n13p293}

\section{Abstract}

The policy gives judicial mediation priority as dispute resolution, which is utilized to coordinate legal, social and political effects. The approach from the state for policy enforcement is evaluation system in courts, which is a form of responsibility system in Chinese court system. Judges and courts face annual targets for permissible numbers of reversed, mediated and closed cases. The previous researches about responsibility system are more about the government administration, specifically the relationship between the central and local government. This paper's purpose is to examine whether the evaluation system in courts is an effective approach to enforce the aforementioned judicial mediation policy, with special reference concerning divorce cases in W Basic People's Court in X city, S province in Northwestern China. The collected divorce cases display the tension between dispute settlement and right protection. The evaluation system is one of the reasons in the tension context that produces the current pragmatism, which in turn is merely capable to partially achieve coordination.

\section{Introduction}

Judicial mediation, as a dispute resolution means, has been greatly emphasized in China over the years for a number of reasons, among which there is its capacity to coordinate legal, social and political effects, which is one of guidelines with which the judicial system serves the whole political system. Since the CPC pays great attention to maintain stability, the judicial system has to work on it due to its involvement in political system. In the Chinese judicial system, numerical evaluation is one of the main administrative approaches for courts management, which ensures policy enforcement in court system.

This paper will examine if the three-effect coordination could be achieved by the policy enforcement approach, evaluation system in courts. According to previous researches, the interaction between responsibility and the legal system in China was a terra incognita in academia (Clarke, 2003). Later on, some research started exploring this area. However, it focused on government administration and pointed out that over reliance on the responsibility system to control local governments and officials is not only against the goal of the legal reform for authorities, but it cannot satisfactorily achieve control on the local government either (Minzner, 2009). This research will broaden the area to see how the responsibility system operates in the judicial system and what its effects are, with special reference to mediation rates.

It will start with the introduction of policy background, interpreting policy expectation for judicial mediation. What follows is the analysis of the responsibility system in China and the evaluation system in courts. The data this paper relies on comes from W basic court in X city in S province, Mainland China, including evaluation structure and mediation rates of marriage-family cases, interviews and mediation observations. It will display the image of judicial practice, in which the three-effects coordination has not been accomplished, since legal right is deemphasized in favour of the pragmatism, which resulted from the evaluation system.

\section{Methodology}

This paper draws on data collected from fieldwork in W court. The reference group is marriage-family cases. There were two fieldwork experiences. One was for the duration of the whole month in March 2012, and the other was from 19 November 2012 to 19 December 2012. W court is located in X city, S province, which is in northwest China. There are two districts in X city. W court is located in W district. It is around 272 square kilometers, including 3 street committees, 47 community committees, 8 counties, and 148 administrative villages. The population there is around 360,000 . W court was established in May 1987. It can take civil, criminal, administrative and enforcement cases. The average caseload of W court is 3,000 per year. The majority of the civil caseload in W court is made of marriage-family cases, which is a good 
pool for this research. There are currently 113 staff members, 61 of which are judges. Among the 61 judges, according to interview, only half of them are dealing with cases, while others are assigned to "serving the people", which entails going to the village to be a communicator, answering legal inquiries from villagers and so on. Accordingly, each judge has to take around 100 cases a year. Administrative tasks take a large percentage of the judges' schedule. The tribunals taking civil cases include first-civil tribunal, second-civil tribunal and two detached people's tribunal. The two detached tribunals are located in rural places and have the jurisdiction of civil cases happened there. Each of them covers four counties in W district.

The evaluation system of $\mathrm{W}$ court will serve as a sample to illustrate the evaluation system in Chinese courts. The data includes the structure of the evaluation system and judicial statistics of civil departments. In this research, the focus was mainly on first-civil tribunal and the $Y$ detached tribunal located in $Y$ County. The first - civil tribunal takes all the civil cases, such as marriage-family dispute, succession dispute, tort, private lending, contact dispute, etc. There are 8 judges and 5 judicial clerks. The annual caseload there is 300 on average. It is located in the court building. Y people's tribunal is one of two detached tribunals of W court. Its annual caseload is around 300 as well. There are 2 judges plus 3 judicial clerks. However, two of the three judicial clerks serve as judges to deal with cases independently. One of two judges is the head of tribunal. It is located in a building on the main street of $Y$ County. The court has the property right of that building.

Apart from the structure description, the fieldwork mainly included participant observation of judicial mediation, interviews with judges, and review of the official related documents. It could contribute to display judicial mediation in action. In March 2012, the majority of time was spent in first-civil tribunal in the court and one week in $Y$ tribunal. Participant observation of 15 marriage-family cases was conducted at that time. When in November 2012, three weeks has been spent at $Y$ detached tribunal and one week in first-civil tribunal and also some interviews in docket office and enforcement office. Observed 16 cases, 10 out of which were marriage-family cases. Moreover, reports were collected of judicial statistic data from 2010 to 2012 in first-civil tribunal and Y detached tribunal, including judicial mediation rate, adjudication rate about marriage-family cases, and voluntary enforcement rate of civil cases. Interviewed judges to know their working experience, educational background and position in the court. Recording the observation and interview process was not allowed. However, taking note and photograph of official documents were permitted. Additionally, in August 2013, the data of mediation rates of family-marriage cases from13 basic courts in X city, including W court, has been collected from the intermediate court of $X$ city.

\section{Responsibility System in China and Evaluation System in Chinese Courts}

It is a typical administrative approach to apply the responsibility system in order to fulfill the government's stabilitymaintenance goal. At the beginning, this system was adopted from the former Soviet Union for industrial management. Later it was applied for administration in government and party committee. In the 1950s, the communist personnel department started to deploy the system to evaluate the performance of cadres, which was used to decide their career development (Barnett, 1967). When it came to the period from the 1960s to the 1970s, in China the political campaign was the mainstream for administrative management. It involved the mass participation, public denunciation and mandatory self-criticism by the assumed officials to supervise the bureaucracy (Harding, 1981). However, it created an unstable political atmosphere during that period. Since the reform, an open policy was put forward in 1979. The responsibility system was deployed again by the Chinese leadership. Specific goals were fixed for cadres to accomplish. The economic development index is taking priority in the assessment.

Since April 1988, the central party committee authorized local party committees to apply the provisional evaluation system for the local cadres. Then in 1999, there was an evaluation system issued by the central organization department, and personnel department to formalize the local trials. However, this document was only applied for the leading or assisting roles of departments or equivalents, and leading or assisting roles of divisions or equivalents in the central party committee, departments in the state council and its directly controlled bureaucracy. (Provisional annual evaluation system for the leading or assisting leading roles in the central committee and state council). The National People's Congress (NPC), the National Committee of the Chinese People's Political Consultative Conference (CCPPC), the Supreme People's Court (SPC), the Supreme People's Procuratorate (SPP), and other People's organizations could make it as reference as well (Provisional annual evaluation system for the leading or assisting leading roles in the central committee and state council). From then on, the evaluation results are used for the sanctions, awards, promotions demotions and training of cadres. The evaluation materials would be in the personnel dossiers (Article 8, Provisional annual evaluation system for the leading or assisting leading roles in the central committee and state council). 


\subsection{Evaluation system in Chinese courts}

Later on, courts around the nation began to adopt the evaluation system for judges. The numerical-oriented evaluation system in Chinese courts is merely a variation of the responsibility system in governments and party committees (Ai, 2008). The numerical tasks for judges include "target ratios of mediation, case closure, appellate reversal, enforcement ratios, average numbers of cases handled by individual judges, and numbers of citizen petitions to higher-level or government authorities generated by citizens discontent with court decisions." (Minzner, 2009)

According to the second judicial reform program (2004-2008), improvement of the evaluation system was set as one of the reform goals. In January 2011, the SPC issued a Notice of the Supreme People's Court on Issuing Several Opinions on Strengthening the Administration of Trials by the People's Courts (Notice of the Supreme People's Court on Issuing Several Opinions on Strengthening the Administration of Trials by the People's Courts). It mentions the evaluation system but not in detail. The general guidance for setting the evaluation system is to guide judges to focus on judicial quality and efficiency, to prevent corruption, and to coordinate the legal and social effects to settle disputes when cases are closed (Article 13, Notice of the Supreme People's Court on Issuing Several Opinions on Strengthening the Administration of Trials by the People's Courts). Then high courts at provincial levels issue specific rules about evaluation system based on local circumstances. Lower courts have to follow such guidelines to establish their own evaluation system. According to the regulation in the Judges Law of the People's Republic of China (2001 Amendment), "the appraisal of judges shall include their achievements in judicial work, their ideological level and moral characters, their competence in judicial work and their mastery of law theories, their attitude in and style of work. However, emphasis shall be laid on the achievements in judicial work." (Article 23, Judges Law of the People's Republic of China)

With the above-mentioned notice and the Judges law in PRC, the evaluation system in Chinese courts can be summarized as follows. Firstly, the evaluation committee in court is a specific organization that is responsible for both judges and departments evaluation. The committee consists of 5 to 9 members, lead by the president of the court (Article 48 and 49, Judges Law of the People's Republic of China). In some courts, the evaluation group or judgment supervision office has been established to execute the duty of the committee. Second, according to judges law, the evaluation is mainly for judges, but actually it is applicable for other functional departments, for example, administrative, financial, personnel, logistic departments and their staff in courts as well, such as administrative staff, judicial police and judicial clerk. Third, as for the evaluation index, the common indexes include judicial quality, judicial efficiency, adjudication capability and research ability. Fourth, the evaluation normally is conducted annually at the end of the year. Fifth, the quantitative evaluation is the common practice in local courts. Finally, based on the evaluation results, the committee makes decision for the career development for judges. (Mu, 2012)

\subsection{W court sample}

In W court, the evaluation system can be divided in two parts: institutional and individual evaluation. The former refers to the evaluation for departments, while the latter means evaluation for individual judges. The individual evaluation can be the base of tribunal evaluation.

\subsubsection{Institutional evaluation system}

Then the institutional evaluation generally includes two parts, the goals for the whole court (administrative evaluation) and goals for tribunals (judicial evaluation). For the administrative section, there are 10 indexes, each of which takes 10 points. For the judicial section, it consists of four parts: trial quality, trial efficiency, trial formalization and trial style, which amount to a total of 200 points. Please refer to the following charts for details. 


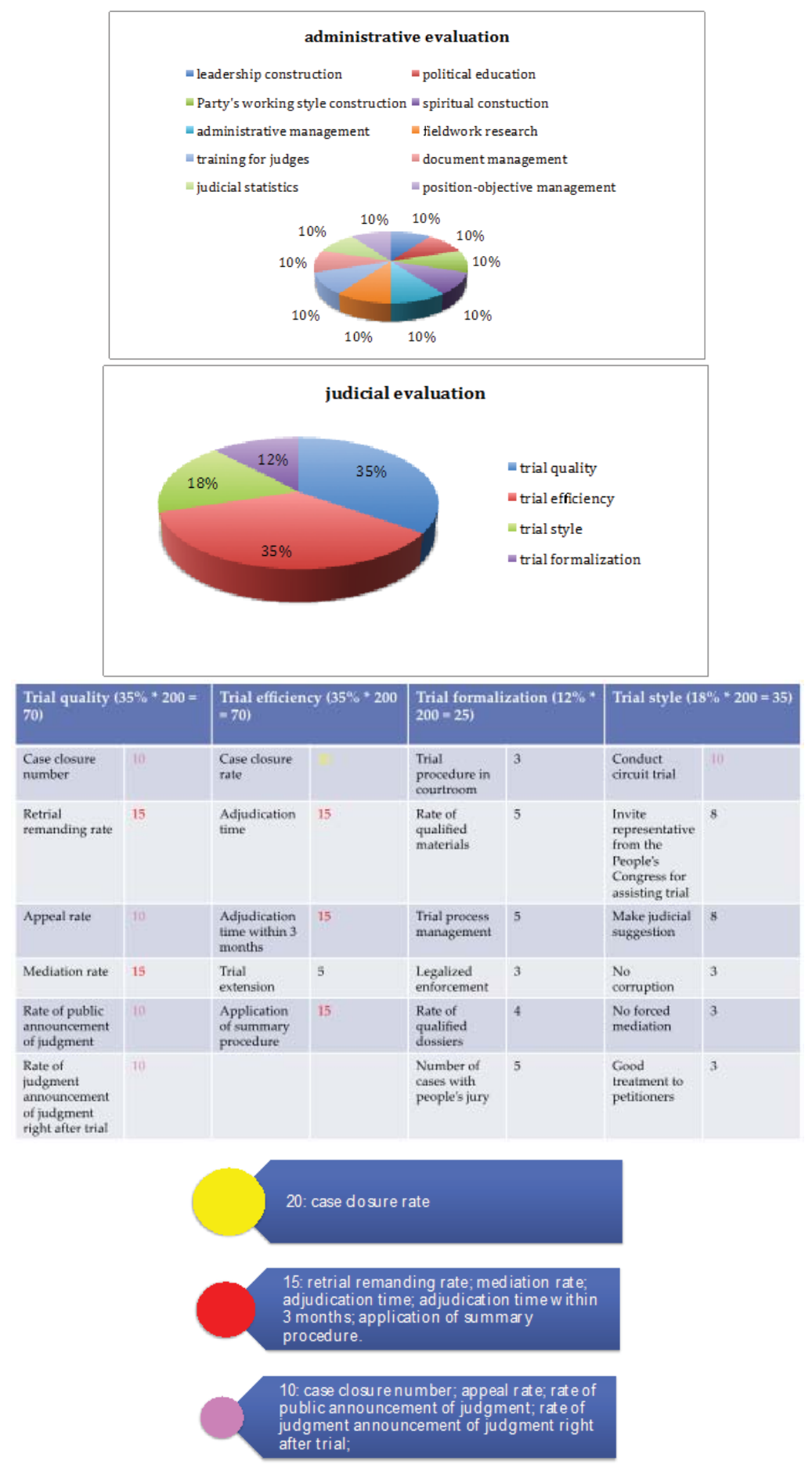

From the forms above, the priority of evaluation can be observed. The dispute settlement takes the priority. The case closure rate is the only one index accounting for 20 points in the whole evaluation system. Then the approach applied 
comes as second concern as well as the trial efficiency. What are following are a few indexes from the trial quality category. It is fair to conclude that the trial efficiency priors to trial quality in evaluation system.

\subsubsection{Individual evaluation system}

As for individual evaluation in W court, it is based on statistic of judge's monthly workload, which includes five parts: case collection, case closure, adjudication time, case without closure and judicial suggestion. Specifically, for the case closure, it covers a few items, such as total number, numbers of adjudication, mediation, jurisdiction controversy, litigation rejection, dismiss, voluntary enforcement rate respectively, number of case resolved by "Wu Jin"1, and closure with successful enforcement. According to the collected data from 2010 to 2012 in two tribunals of W court, the data is not recorded completely by and large. Only a few of them are fully recorded each month, such as number of case closure, number and rate of adjudication, number and rate of mediation, voluntary enforcement rate, adjudication time, number of not closed case and number of "Wu Jin". The orange-highlighted indexes are the ones with monthly records, which are emphasized in evaluation.

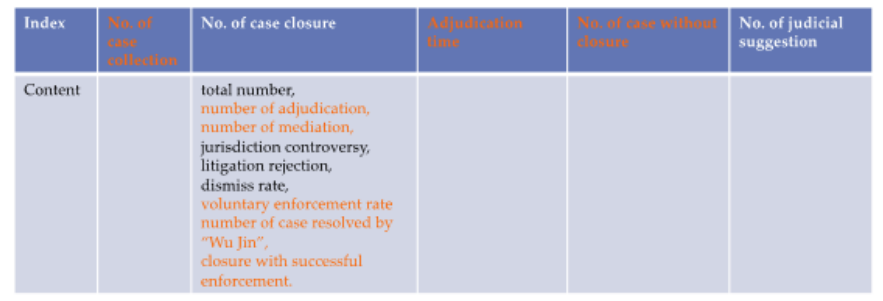

\subsubsection{Analysis on evaluation system}

Overall, the evaluation in W court has these characteristics as following.

To start with, both institutional and individual evaluations are quantitative. For institutional evaluation, it not only quantifies the trial quality, but also the trial style. Generally, trial quality and trial efficiency take majority of the evaluation (70\%). The individual evaluation for judges mainly follows the indexes of trial quality, efficiency, and minor part of trial style. However, both individual evaluation and institutional evaluation are conducted monthly and annually. The ranking will be published in the lobby of main building in $\mathrm{W}$ court.

Then this evaluation system is consistent with the requirements from the intermediate people's court. Normally basic people's court designs its evaluation system according to the requirement from the intermediate people's court. In $X$ city, According to the requirements of the intermediate court, the rate of case closure should be $95 \%$ or above, the rate of appeal with revised judgment $20 \%$ or below, rate of remanded retrial $5 \%$ or below, rate of case with jury $10 \%$, mediation-withdraw rate of civil cases $80 \%$, rate of "Wu Jin" $20 \%$, etc.

\section{Interpretation on mediation rate}

\subsection{Institutional interpretation}

Literally, mediation rate is an index displaying the proportion of disputes settled by judicial mediation. According to the official propaganda mentioned above, judicial mediation can be a good approach to achieving harmony and dispute settlement, which is supported by cultural interpretation. However, the institutional design would explain that how judicial mediation makes dispute settled. Once the case is settled, it is settled. The supervision of dispute resolution cannot be applied for mediated cases at most times.

At present in China, the court system is a four-level hierarchy, basic people's court, intermediate people's court,

1 "Wu Jin" (五进) is one of activities promulgated by the court, which requires judges to walk into the villages, schools, communities, enterprises and militaries to proceed with the trial. The functions of such propaganda are legal education and serving for people, which keeps accordance with Chinese judicial activism. 
high people's court and supreme people's court in sequence. ${ }^{2}$ Apart from these courts, there are also some special courts, such as military courts. The SPC supervises all of the local courts. As for the relationship among the local courts, generally the higher-level courts supervise the lower-level ones within the same administrative location. The procedures for supervision are normally including the appeal (Article 164, Civil Procedure Law of the People's Republic of China), trial supervision procedure (Article 198 and 199, Civil Procedure Law of the People's Republic of China), referral system and petition.

According to the Civil Procedure Law in the People's Republic of China, the trial procedure are categorized as following, the first instance, the second instance, and supervision procedure. Cases go to various levels of courts according to case merits for the first instance. Then the appeal could be made to the higher-level court. The supervision procedure depends on the instance in which cases applied ended with (Article 207, Civil Procedure Law of the People's Republic of China). There is a summary procedure at the first instance, which could be applied for the minor cases with conditions (Article 157, Civil Procedure Law of the People's Republic of China). In some context, a few of the minor cases applied for summary procedure cannot go to the second instance (Article 162, Civil Procedure Law of the People's Republic of China). Generally, the formal trial procedure will end at the second trial. The supervision procedure is designed to revise wrong judgments. Besides the case parties, there are merely a few people or judicial system can start such procedure (Article 198 and 208, Civil Procedure Law of the People's Republic of China). In all, for the majority of cases in Chinese courts, they can go as far as second trial.

As for the referral system, to be more specific, it has been part of the judicial institutions since the establishment of the PRC. At the beginning, on 19 September 1958, the SPC issued a document to improve the referral system in courts (The reply from the SPC about how to improve the referral). As the regulation from the SPC and common practice, there are a few types of cases for referral. Firstly, it is merely applied for the legal issue other than factual issue. Secondly, the case facts have to be clear enough for the referral. The courts, which make the application for referral, should prepare the clear facts with evidence. Otherwise cannot apply for referral. Thirdly, the opinion of majority members in the adjudication committee in the courts should be formed. Fourthly, other minor opinions should also be displayed in the application. Fifthly, the referral application should be made level by level. It is not allowed to bypass the higher-level court. Sixthly, the referral case has to be legally complex enough or qualified by related rules. Finally, the application should be made in written form. The referral system was mentioned in the second five-year judicial reform program. According to Article 12, the scope for referral case has been broadened. Not only the cases with legally complex issue can be applied for referral, but also the cases can be precedents (First five-year reform program of People's court and second five-year reform program of People's court). Such measure directs the system to a positive orientation. Originally it is merely an approach for authority distribution. Currently it is on the way to serve the case guiding system.

Finally, there is another system for dispute resolution in China except the aforementioned ones, the petition. Generally, the petition can be made directly to the concerned court, local government ${ }^{3}$ or local political-legal committee. For people from undeveloped area, they would like to choose the authority they suppose to be superior in their mind. Whether the parties could make petition about mediated cases in courts, there is no specific stipulation. In 2012, the chief justice of the SPC pointed out the four necessities and five institutions to improve petition work. Four necessities indicated, "It is necessary to implement the mass line, control the origins, establish long-term system, and shift down the work focus." The five institutions included "evaluation and prevention, reception and communication, responsible report, multiple resolution, and case closure." (Wang, 2012) The rate of petition is also one of the indexed to evaluate the job that court has done in stability maintenance. It is like another kind of feedback from the parties after the official judicial procedure.

Seen from the above, the current stipulations in civil procedure law follow legal formalization, which has been the aim for rule of law construction in China for a few recent decades. The function of the due process is to deliver the justice to the parties in the end. However there are a few interpretations for settling disputes in context of judicial mediation. Firstly, settled dispute means closed case. For litigation, the procedure can start from the first instance to the second instance, or even ends with the supervision procedure. The caseload of court is increasing at a staggering rate in China. The rate of case closure is one significant index to evaluate the judicial work. The higher rate of case closure, the better job has been done. The higher rate of case closure predicts that less possibility for conflicts happen on a larger scale. In

2 Their jurisdictions are assigned to the administrative level. The jurisdiction of basic people's court is within district in a city. The jurisdiction of intermediate people's court covers the city. That of the high people's court takes charge of the whole province or municipality. Finally, the SPC covers the whole country.

${ }^{3}$ There is a specific department in government, the petition bureau. However, the petitions are not limited to this department. In most cases, people will stand for their ground in front of the government building since they are not allowed to enter into the department. 
judicial practice, mediation is a helpful approach attributing to the higher rate of case closure. The reason is exactly the institutional design for mediated cases. For example, during fieldwork, there was a divorce case. The husband sued his wife for a divorce. There was no child or property in common. The only claim is divorce. Actually the plaintiff sued nearly half year ago and the judgment did not allow divorce. There is an article in Chinese civil procedure law about divorce litigation, which stipulates if parties get judgment not allowing divorce, they cannot sue again without new reason or new circumstance. Reluctantly, the plaintiff in this case filed second time just a few days before the due day. But the docket tribunal made the registration. When the case came to $Y$ people's tribunal, judges informed the plaintiff he had to drop the case and waited for another six-month litigation-forbidden period. There was a debate among judges, if the parties have to follow the regulation in such context. In the end, they reached a unanimous consensus that what they need to take care is only this time. If the plaintiff dropped the case, one case can be closed. ${ }^{4}$ It would contribute to the closure rate and mediation-withdrawing rate as well without any effort.

To be more specific, case closure for mediated cases also means no appeal to the higher-level courts. If the case was resolved by judicial mediation, there is no appeal afterwards. According to civil procedure law, only the supervision procedure could be remedy for mediated cases with condition (Article 198 and 199, Civil Procedure Law of the People's Republic of China). However, in most cases, disputes actually could be resolved by judicial mediation in the first instance. The supervision procedure is rarely applied for mediated cases. Without supervision procedure, the dispute would be supposed to be resolved from the perspective of the courts at least. In judicial practice, the mediation rate and appeal rate always go opposite direction, while the adjudication rate goes the same direction with the appeal rate. Overall, settling dispute by judicial mediation to some extent means to resolve dispute from procedural aspect. The effective judicial mediation attributes to the higher case closure rate, and lower appeal rate.

\subsection{Individual motivations to conduct judicial mediation}

As mentioned above, the evaluation of judges will impact their career development, which is the same with that for government cadres. Whether the numerical tasks have been accomplished or not, it decides award or punishment for judges. As for the incentives for judges to conduct judicial mediation, generally it can be summarized as four factors, bonus, honor, and autonomy.

Firstly, it is the benefits that judicial mediation would bring. Normally incomes of judges will not be disclosed. The income is consisted of two parts, one of which is salary related with administrative level, and the other part is the case bonus decided by the caseload the judge processes. It is fair to predict that judge's salary is individually different. According to the interviews in fieldwork, the salary difference among administrative levels is about 500 RMB in W court. The case bonus in $\mathrm{W}$ court varies with the approach closing the case. Specifically, a judge who closes a case by judgment, the judge could get 120 RMB as case bonus. If by judicial mediation, the bonus could be 180 RMB. Furthermore, if the mediated case with immediate enforcement, bonus could be $220 \mathrm{RMB}$. The salary related with administrative level in W court is not as high as that of courts in developed region. For example, the entry level will be around $1500 \mathrm{RMB}$ per month. The difference between the bonuses by judgment and mediation is $60 \mathrm{RMB}$ or even 100RMB. In this case, if a judge closes 10 cases by mediation with enforcement, he or she would double the salary. Compared with the relatively low salary, the bonus could be attractive for judges to increase income.

Secondly, with high mediation rate, the judge would be entitled with honour. In most cases, the title could be judicial mediator model or mediation expert. The award presentation will be held in the courts. What's more, the propaganda would be delivered by the media, both the official and commercial mass media. The stories about their judicial mediation are displayed in front of the populace. ${ }^{5}$

Model judges are good at judicial mediation as reported, which could be proved by the high mediation rate they have achieved, which means lower petition rate and appeal rate. For example, Bai Jie, a judge from Shanxi, her mediation from 2006 to 2007 was $72 \%$ with no petition or appeal. ${ }^{6} \mathrm{He}$ Yunxia, head of a people's tribunal, achieves

\footnotetext{
${ }^{4}$ A divorce case was observed on 26 November 2012 in W court.

5 Google by terms "judge + mediation expert" (法官 + 解能手调), the results reports are $112,000$. http://www.google.com.hk/\#q=法官+解能手调\&hl=zh-

TW\&tbo=d\&ei=RefyULmAE4zdkgXf2IHIDQ\&start=0\&sa=N\&bav=on.2,or.r_gc.r_pw.\&bvm=bv.1357700187,d.aGc \&p=e7433be0921bda7d\&biw=1218\&bih=684, accessed 5 January 2013.

6 'Brilliant achievement by national emblem: anecdote of Judge Bai Jie', http://yh.yaowenhua.com.cn/contents/54/694.html, accessed 16 July 2013.
} 
mediation rate of $80 \%$ with voluntary enforcement rate above $95 \% .^{7}$ The judge who is mentioned above, Huang Danfeng, achieves mediation rate as $63 \%$ and was recognized as the provincial skillful mediator in $2007 .{ }^{8} \mathrm{Ma}$ Xinying's mediation rate is $80 \%$ without petition or appeal. ${ }^{9}$ Zhai Shuquan, a judge from a people's tribunal, achieves mediation rate as $90 \%$ without petition or appeal. ${ }^{10} \mathrm{Additionally,} \mathrm{among} \mathrm{the} \mathrm{available} \mathrm{materials,} \mathrm{other} \mathrm{model} \mathrm{judges'} \mathrm{mediation} \mathrm{rates} \mathrm{are} \mathrm{listed} \mathrm{as}$ following, Judge Zhuang Jinkui 85\%11, Judge Cai Shengpu 60\%12, Judge Zhu Mei, 90\% in 2009 and $70.4 \%$ in $2010^{13}$, Judge Chen Shengxiao, 97\% from 2005 to $2010^{14}$, Judge Yu Shengqing 90\% ${ }^{15}$, Judge Huang Denglin 87.7\% in 2008, $99.51 \%$ in $2009^{16}$, Judge Liang Shan $90 \%{ }^{17}$, and Judge Ma Ziying $86 \%{ }^{18}$. Without doubt, those judges who have achieved high mediation rate have been awarded as excellent mediator.

Finally, judges could have judicial autonomy when they apply judicial mediation to close cases. As mentioned above, the adjudicating judge can make his or her own decision to control mediation process and guide the result. The collegiate system and supervision procedure are barely activated in context of judicial mediation. In Chinese courts, the judgment has to be censored by head of tribunal and vice president in charge or president of the court before it is issued. However, for judicial mediation settlement, the head of tribunal can make final decision.

In all, the institution does provide incentives for judges to prefer judicial mediation to adjudication. Numerical evaluation system has been rooted in court system, which is consistent within the system. The evaluation system is working as a map for judges to adjust their focus. In the end, the assessment result will lead the judges to various ending. Good performance will bring the bonus, honour and promising career future. Otherwise, criticism, demotion or replacement would follow.

\section{Judicial mediation in action: data analysis}

\subsection{Unsatisfying mediation rate}

The data of mediation rate collected for this paper includes two parts. One part is the mediation rate of marriage-family cases of 13 basic courts in X city from 2009 to the first half of 2013. The reports were collected from the intermediate court of $X$ city in August 2013. It is the result of institutional evaluation. The evaluated objectives are courts. The higherlevel court ranks all the basic courts both monthly and annually. The other part is mediation rates from two tribunals in $\mathrm{W}$ court respectively; first-civil tribunal from 2011 to 2012 and $Y$ detached tribunal from 2010 to 2012. This part is calculated based on individual evaluation, the monthly workload statistic of individual judges.

Formally, requirement from the intermediate court should be $80 \%$. However, according to the statistic report from the intermediate court, rates from local courts are not satisfying, which displays around $49 \%$ of collected rates is lower than $80 \%$. Specifically, in W court, mediation rate was $73.3 \%$ in 2009, 79.5\% in 2010, 77.2\% in 2011, 84.4\% in 2012 and $83.8 \%$ in $2013 .{ }^{19}$ Furthermore, it is also important to notice that the difference between results of official court reports and statistic based on the calculation of individual judges' workload exists. From the court report to the intermediate court, the

\footnotetext{
${ }^{7}$ 'Considerate judge in mountain area for the people: anecdote of Judge He Yunxia', http://fanfu.people.com.cn/GB/15811570.html, accessed 16 July 2013.

8 'Huang Danfeng: National excellent judge' http://sjtfy.chinacourt.org/public/detail.php?id=180, accessed 16 July 2013.

${ }^{9}$ Chunyu G, 'Pride of Hui Nationality' 11 Chinese Judgment 80, 80.

10 'Impartial Judge Zhai Shuquan', http://dangjian.people.com.cn/n/2013/0708/c117092-22113062.html, accessed 16 July 2013.

11 'Deputy of Shuyang court has been selected as national model judge', http://js.people.com.cn/html/2012/02/15/79380.html, accessed 17 July 2013.

12 'Female judge Cai Shengpu: gentle and decisive', http://ah.anhuinews.com/system/2013/06/17/005772480.shtml, accessed 16 July 2013.

${ }_{13}$ 'Zhu Mei: set up good image for modern judges', http://gjfs.com.cn/mos/cms/html/255/1654/201208/15790.html, accessed 16 July 2013.

14 'Deputy of Xiao Guan people's tribunal of Xuan En county court practices people's justice', http://www.hb.xinhuanet.com/201203/01/content_24811234.htm, accessed 17 July 2013.

15 'Judges from basic court should strive on mediation', http://www.legaldaily.com.cn/Social_management/content/201209/13/content_3840137.htm?node=35348, accessed 16 July 2013.

16 'Mediating dispute with emotion, making harmonious relationship', http://gxllfy.chinacourt.org/public/detail.php?id=60, accessed 17 July 2013.

17 'Judge Liang Shan hold harmony with sincerity', http://www.brian-collins.net/xinwen/ayx_456.html, accessed 17 July 2013.

18 'Judge Ma Ziying from Xia Ma Guan people's tribunal of Tong Xin County court: move the tribunal to village yard', http://news.sohu.com/20100803/n273945524.shtml, accessed 16 July 2013.

19 Data was collected from $\mathrm{W}$ court.
} 
average mediation rate of marriage-family cases in W court from 2011 to 2012 was $80.8 \%$, while the average mediation rate of first-civil tribunal at the same time was $69.5 \%{ }^{20}$ and $57.6 \%$ in $Y$ detached tribuna| ${ }^{21}$. The other detached tribunal has the similar situation to $Y$ tribunal. The mediation rate task has not been accomplished to a satisfying extent.

\subsection{Deemphasis on right protection}

Except failure on quantitative aspect, it is doubtful as well if the coordination of three effects has been achieved in judicial mediation. The mediation rate could merely display dispute has been settled procedurally regardless of right protection. Under the pressure of evaluation and incentives brought by mediation, judge would like to risk right protection for dispute settlement. The amicable settlement should have been formed based on the agreement from both sides. However, pragmatism makes mediation result merely as dispute settlement.

In this paper, one case involving the right of children of divorced couple would be referred to support aforementioned argument. Specifically, according to the marriage law, rights of children include being raised and visited by divorced couples. If any dispute happens, which cannot be settled by couples, it shall be settled by the people's court according to the specific conditions of both parties and in light of protecting the rights and interests of the children. (Article 36, Marriage Law of the People's Republic of China). In China, laws for marriage-family legal relationships mainly include the Marriage Law of People's Republic of China plus its three judicial interpretations. Additionally, there are a few interpretations for specific circumstances, such as domestic violence (Guide for Hearing Marriage Cases Involving Domestic Violence). The regulations mentioned above are not specific enough for right protection from aspect of doctrinal analysis. Furthermore, in judicial practice, pragmatic judicial mediation makes right protection deemphasized compared with emphasis on dispute settlement.

The case fact is the couple wife $L$ and husband $C$ had a daughter who is merely 1.5 years old. The wife claimed for a divorce and she also would like to get back her dowry. There was no common property since they were newly married. She did not claim custody of her daughter. Judicial mediation was deployed through the whole procedure.

\subsubsection{First part: mediation before trail}

The adjudicating judge tried mediation even before the trial, which started from their attitude of divorce. "What do you think about divorce?" Both of the parties agreed on a divorce. However, they cannot reach to the agreement on child custody and property division. Normally when divorce cases reach to court, it is not difficult to predict the attitude of divorce from the couple. If they feel satisfied with children' custody or property division, agreement on divorce should be reached without question. After locating the controversy, judge started collecting more information to proceed with mediation. The agents of both sides were quite active in this case..$^{22}$ The mediation stated with the custody issue. In this case, both sides would not like to take the child custody. The wife would like to hunt for a job and she thought the child would be a burden for her to carry, while the husband argued that he cannot raise the child on his own since he had already separated living from his parents due to their conflict between the wife. After getting knowledge of opinion from both sides, the adjudicating judge put forward her "suggestion" to probe the bottom line of the couple. "Then you may send your child to adoption, since none of you would like to take care of her." Suddenly, the husband responded with a compromise: "let her take the custody, I can offer more money." Then the agents from both sides mentioned a proposal formed before the mediation, which was the wife takes the custody, and the husband would give her 1,000 RMB per month. But the couple could not accept it.

After this exploration, the judge changed the focus back to the attitude of divorce, which was a strategic move. If no divorce, there would be no need to discuss about child's custody assignment. Here the agents were active again. The judge even suggested temporary separation to the wife to relieve conflict. "Can you just lead a separated life from Chen's parents without divorce currently?" Both sides did not take this option. Then the judge had to start the private session with each party.

When the judge was having private session with the wife with the attendance of agents from both sides. She first played the card of child's interests with the wife. Then tried to persuade her to ignore the mother-in-law, who should be one of the main reasons of the divorce case. When the wife was about to tell story about family conflicts with her

\footnotetext{
20 Data was collected from $\mathrm{W}$ court.

${ }^{21}$ Data was collected from W court.

22 Both of the agents are not professional lawyers. They are judicial workers who are trained and tested by the local justice department. Then they can practice in local areas. Normally they charge less than professional lawyers. People usually go for them for minor cases.
} 
husband or his mother, the judge directed her to think about her husband's good personality. Once again, the judge offered her the suggestion of separated living for half year without divorce, with the condition that she should take custody of child with 1,000 RMB per month from her husband. "What do you think about? Give him half year for improvement. He will give you 1,000RMB to support custody till child goes to the kindergarten. Then when you can get a job, the fee could be decreased." The bargaining between the wife and agent of her husband was following after that the wife turned down the judge's offer. During this process, the judge took the side of the wife. She even checked if she was already seeing someone at that moment and would like to get remarried soon. It is another gesture to probe the bottom line. This private session ended with the effort of the plaintiff's agent to persuade the wife to take judge's offer.

Then it was the time for private session with husband, while the agents of both sides were present as well. The judge did not uncover bottom line of the wife, instead of which she checked the opinion of husband at the beginning. "What do you think about the custody?" The husband answered, "1000 RMB per month, live separately some time before divorce. How about her opinion?" The judge did not tell him. "Leave her alone. Talk about your opinion first." With the persuasion from agents from both sides, husband started complaining. "I feel I did nothing wrong. She always has conflicts with my parent. I have to sleep for only 3 hours at night to make sure earning enough money to raise the child. She mentioned about divorce to my parent frequently." However the judge just cut it off. "Such trivial stuff you need to be tolerable." Then judge guided mediation back to controversy and tried possible solutions again. However, the bad relationship between the wife and family of her husband was the toughest barrier to reach dispute resolution. The husband would not like to compromise on this aspect. When the judge realized that a divorce may have to be granted, the child' custody still could be the controversial issue, which cannot be mediated. The trial had to be opened.

\subsubsection{Second part: mediation at the beginning of trial}

Then they moved to courtroom from judge's office to open the trial. However, the mediation was still deployed instead of an official trial at the outset. After the aforementioned process, all of the discussions were focusing on child's custody cost. The husband only agreed on 1,000 RMB per month for the wife taking custody. However, the wife would not agree with it unless the husband could pay for 1,500 RMB monthly. Consequently, 500 RMB difference became the part that judge needed to work on. Then the husband made a compromise eventually. "I mentioned before, we need some time to save our relationship. If possible, we can remarry in the future." Said by the husband. However, the wife was so determined that mediation failed once more.

\subsubsection{Third part: trial}

After twice mediations, the trial went on finally with clear controversial issues. Based on the claims from plaintiff, after the issue of custody, the visitation finally was mentioned. However no agreement can be reached in the end. During this process, judge mainly focused on fact exploration. The trial started with the claim from plaintiff, "file for divorce; do not claim for custody; pay for custody: 100RMB; and claim dowry back. Additionally, the defendant pays for the litigation fee. They got married in 2012. The relationship between them was broken since the childbirth. When the defendant made his defense, he agreed to divorce, but insisted that the dowry should not be refunded. Moreover, he claimed the money back that he gave her for engagement, 1,000 RMB. Then in the trial procedure, judge checked with both parties about their attitude of divorce. With the positive attitude from both, the judge quickly concluded the controversies. "As for the visitation right, it's legal and not controversial. Now the controversies are dowry, gift money and child custody. You can argue about these points." Then the judge continued to check the current situation of custody. The husband was taking care of the kid at that time. The requirement of visitation issue from the wife was two to four days per month. Finally the issue of custody was distracted by the defense of husband's agent, when he mentioned about the common debt right "We insist that she takes the child. First is the mother's love cannot be replaced. And then the job of defendant is not stable enough to support both his and the daughter's living. They have a debt in common, 5000. Her cousin took the money." These defenses made the disputed couple start arguing again. In the end, the judge announced that there was no need to conduct another mediation during the trial.

\subsubsection{Fourth part: mediation after trial}

Although judge mentioned above that there was no need to conduct another mediation, she offered another option for child's custody. "What do you think about this? One of you takes the child for a year and the other for another. Cover the 
cost in your own shift, no matter how much expense of your own year." Then the sequence, which one would take the first round, became new issue. Neither of them would like to be the first. Finally, the judge announced, "since no agreement can be reached, we will decide. When the child grows up, you guys can discuss it again."

\subsubsection{Result and summary}

According to the second interview of the adjudicating judge, the case was finally mediated. However, at the beginning, the mediation agreement followed the suggestion of the judge, which meant that the divorced couple took custody in turns and covered the expense during their own shift. But they cannot agree on that if the dowry could be returned. Consequently the mediation process was interrupted after the trial. In the end, the wife made compromise to achieve mediation after half year. She would like to take the custody and gave up the claim of dowry. That was how the settlement was formed.

The adjudicating judge of this case tried mediation from the beginning to the end. The focus was the custody and its cost. She tried to probe the bottom line of the parents regarding to the custody assignment. In order to achieve it, she even suggested sending the child away for adaption, although it was merely a strategic move. The right related to the child, such as visitation, was rarely mentioned in mediation. It appeared in her trial discourse, which was covered by one sentence. "It was stipulated in law." In the end, she proposed that the parents could take custody in turn till the kid grows up. The court would decide who should start. This move could solve the problem of disagreement on custody cost albeit regardless of the child's interests.

\section{Conclusion}

As for the topic in this research, judicial mediation, in basic court, pragmatism is an unavoidable consequence for the increasing policy emphasis on judicial mediation and evaluation on judicial system and judiciary. From the perspective of leadership, the policy objectives are designed to serve the political needs, settling disputes and keeping peace. Hopefully in the end it can contribute to the social stability maintenance. It is the way to illustrate legal pragmatism in Chinese context.

As observed, the SPC indeed caters to the policy calling from the CPC. It is the institutional pragmatism that motivates the SPC to follow the popular guidance in order to get well prepared for professional development. The SPC has to sacrifice, promoting populism to a limited extent, in order to win more time and financial support for future professional development (Zhang, 2012). It could stand as an explanation for the SPC, which formally is the leading role in court system except the central political-legal committee.

However, it has different forms of pragmatism in lower courts compared with the institutional pragmatism for the SPC, such as closing cases, settling disputes, getting more pay, receiving honour, etc. In the current situation, the zealous promotion of mediation from the SPC in the whole court system could be effective for long-term consideration, since it would contribute to lower petition rate, which will get credits for the court system in the whole political system. In the end, it may be helpful for future professional development (Zhang, 2012). However, the SPC rarely conducts mediation for civil cases. More than 90\% judicial mediation for civil cases happened in basic courts.

Finally pragmatism is the way judiciary takes to enforce judicial mediation policy in basic courts. To conduct judicial mediation there, judge has to act more like mediator than legal professional. Judicial procedure has to be flexible to facilitate judicial mediation. Pragmatism in basic courts has been expressed as de-emphasis on right protection in judicial mediation.

Is the evaluation system contributing to achieve policy objectives of judicial mediation regarding to coordination of legal, social and political effects? After the analysis above, it is the time to answer this question. The coordination is not appropriately achieved, since the right protection has been deemphasized in judicial mediation. The emphasis on mediation rate results in pragmatism, which would give priority to dispute settlement instead of right protection for parties.

\section{Reference}

Ai Jiahui (2008). Research on Chinese Court Performance Evaluation System. Law \& Society Development, 83 70-84.

Barnett A.D. (1967). Cadres, Bureaucracy, and Political Power in Communist China, New York: Columbia University Press.

Civil Procedure Law of the People's Republic of China, http://en.pkulaw.cn/display.aspx?cgid=183386\&lib=law, accessed on 5 January 2013.

Clarke D.C. (1987). Empirical Research into the Chinese Judicial System. In Erik G. Jensen TCH (Ed), Beyond Common Knowledge: 
Empirical Approaches to the Rule of Law (pp. 164-178), Red Wood: Stanford University Press 2003.

Harding H (1981). Organizing China: The Problem of Bureaucracy, 1949-1976, Red Wood: Stanford University Press 1981).

Judges Law of the People's Republic of China (2001 Amendment)', http://en.pkulaw.cn/display.aspx?cgid=35754\&lib=law, accessed on 23 July 2013

Minzner C.F. (2009). Riots and Cover-Ups: Counterproductive Control of Local Agents in China. University of Pennsylvania Law School Journal of International Law, 31, 53-123.

Mu Run (2012). Analysis and Improvement on Court Evaluation System. Journal of Yunnan University Law Edition 25, 141-146.

O' Brien K. J. \& Li Lianjiang (1999). Selective Policy Implementation in Rural China. Comparative Politics, 31, 167-186.

The Central Party's Organization Department \& State Council. (1989) Provisional annual evaluation system for the leading or assisting leading roles in the Central Party's Organization Department and state council. http://law.lawtime.cn/d647137652231_1_p1.html, accessed on 5 January 2013.

The Supreme People's Court. First five-year reform program of People's court and second five-year reform program of People's court. http://www.legaldaily.com.cn/zbzk/2009-04/30/content_1091822.htm, accessed on 5 January 2013.

The Supreme People's Court. Notice of the Supreme People's Court on Issuing Several Opinions on Strengthening the Administration of Trials by the People's Courts. http://en.pkulaw.cn/display.aspx?cgid=151505\&lib=law, accessed on July 232013.

The Supreme People's Court. The reply from the SPC about how to improve the referral. http://www.pkulaw.cn/fulltext_form.aspx?Db=chl\&Gid=175236\&keyword=最高人民法院关于改进请示解答工作的函 \&EncodingName=\&Search_Mode=accurate, accessed on 5 January 2013.

Wang Shengjun. Implement four necessities and five institutions to improve petition work. http://www.court.gov.cn /xwzx/fyxw/zgrmfyxw/201204/t20120405_175695.htm accessed on 5 January 2013.

Zhang Taisu (2012). The Pragmatic Court: Reinterpreting the Supreme People's Court of China. Columbia Journal of Asian Law, 251 61. 